\title{
Development and functional morphology of the larval foregut of two brachyuran species from Northern Brazil
}

\author{
FERNANDO A. ABRUNHOSA, DARLAN J.B. SIMITH, JOÉLY R.C. MONTEIRO, \\ ANTONIO N. DE SOUZA JUNIOR and PEDRO A.C. OLIVA \\ Laboratório de Carcinologia, Instituto de Estudos Costeiros (IECOS), Universidade Federal do Pará (UFPA), \\ Campus Universitário de Bragança, Alameda Leandro Ribeiro s/n, Aldeia, 68600-000 Bragança, PA, Brasil \\ Manuscript received on May 28, 2010; accepted for publication on September 15, 2010
}

\begin{abstract}
Feeding is an important factor for the successful rearing of larvae of the crab species. Further information on the morphological features of the foregut may to reveal larval feeding behaviour and or/whether there is a lecithotrophy in some or even in all stages of the larval cycle. In the present study, the structural development of the foregut and their digestive functions were examined in larvae of two brachyurans, Uca vocator and Panopeus occidentalis, reared in the laboratory. During larval development, the foreguts of the larvae in the first and last zoeal stages and in the megalopa stage were microscopically examined, described and illustrated. The zoeal foreguts of both species were well developed, showing specialization with a functional cardiopyloric valve and a filter press. The megalopa stage had a complex and specialized gastric mill similar to that found in adult crabs with the appearance of rigidly calcified structures. These results support the hypothesis that the feeding behaviour of each larval stage is directly related to the morphological structure of the foregut. Such facts strongly indicate that all larval stages of both U. vocator and $P$. occidentalis need an external food source before completing the larval development in a planktonic environment.
\end{abstract}

Key words: digestive system, megalopa, Panopeus occidentalis, stomach, Uca vocator, zoea.

\section{INTRODUCTION}

Feeding is an important factor that significantly affects the larvae of several brachyuran crab species, although an external food supply may not be necessary in the case of lecithotrophy, where some larvae reach the subsequent larval stage or even complete larval development without external food (Kittaka 1988, Nishida et al. 1990, Kittaka 1994, Anger et al. 1995, Abrunhosa and Kittaka 1997a, b, Nates and McKenney Jr 2000, Anger 2001). Some species, however, may present a facultative lecithotrophy when external food is not available (Anger et al. 1995, Thessalou-Legaki et al. 1999, Anger 2001). Therefore, further information concerning suitable feeding measures for larval rearing is needed, and

Correspondence to: Fernando de Araújo Abrunhosa E-mail: faraujo@ufpa.br this is critical for the successful rearing in the laboratory of this crab species.

Examinations of the behaviour and characteristics of larval morphology in species reared under laboratory conditions may contribute to this knowledge, and may also provide an understanding of the complex biological and ecological relationships which that occur among these species in the nature (Anger 2001). Detailed morphological studies of the decapod digestive system have demonstrated a close relationship between the morphological characteristics of the digestive system and feeding behaviour (Nishida et al. 1990, Abrunhosa and Kittaka 1997a).

Evidences of food abstinence were observed during the transitory stage (puerulus) in larvae of lobsters belonging to the genera Panulirus, Jasus and Palinurus (Kittaka 1988, 1994, Kittaka and Ikegami 1988, Kit- 
taka et al. 1997). In these species, a noticeable morphological change was observed in the digestive system during metamorphosis, which showed as well as a reduction of the mandibles and the setal number in the external feeding apparatus and showed an underdeveloped foregut (Nishida et al. 1990, Wolfe and Felgenhauer 1991, Mikami and Takashima 1993, Lemmens and Knott 1994). Abrunhosa and Kittaka (1997a, b) observed similar facts in king crab species of the genus Paralithodes (important fishery resource of the North Pacific) during the megalopal stage. More recently, a similar behaviour was also observed in zoeal stages of the callianissid Lepidophthalmus siriboia (Abrunhosa et al. 2006).

In previous studies, the development of the foregut and mouthparts have contributed to the better understanding of the feeding behaviour of a cultured species, which has allowed the identification of an adequate feeding regime and, consequently, has enhanced the survival rate during larval development (Nishida et al. 1990, Minagawa and Takashima 1994, Abrunhosa and Kittaka 1997a). Many studies have focused on the morphological and functional aspects of the foregut in adult decapod specimens (Meiss and Norman 1977, Kunze and Anderson 1979, Suthers and Anderson 1981, Suthers 1984, Skilleter and Anderson 1986, Mikami and Takashima 1993, Pinn et al. 1999, Jha and Homechaudhuri 2001, Brosing et al. 2002, Castro and Bond-Buckup 2003), however, very few efforts to investigate these aspects in the larval stages have been undertaken in the past. Therefore, in this present study, the morphology of the larval foreguts of two decapod crabs from the Northern Brazil, Uca vocator Herbst 1804 (Ocypodidae) and Panopeus occidentalis Saussure 1857 (Xanthidae) were investigated, and the functionality of these organs is discussed in detail.

Detailed morphological descriptions of these two were previously reported by Ingle (1985) and Rieger (1999) for P. occidentalis and U. vocator, respectively. Biogeographically, adults of both species are found in mangroves and in the estuarine areas along the coast of the Americas (Atlantic South). In Brazil, these species occur in mangrove areas from state of Pará, northern Brazil, to the state of Santa Catarina, southern Brazil (Melo 1996, Diele et al. 2010).

\section{MATERIALS AND METHODS}

\section{LARVAL REARING}

Larvae were obtained from egg-berried females of $U$. vocator and $P$. occidentalis collected one day before hatching in the mangroves of the Caeté river estuary (Northern Brazil). The females were transported to laboratory where they were washed and kept individually in aquaria (5 L) filled with seawater and constant aeration. The crabs were maintained in ambient temperature $\left(26^{\circ} \mathrm{C}\right)$, salinity $30, \mathrm{pH} 8.0$ and without food until larval release.

After hatching, the zoea larvae were transferred to plastic recipients filled with $150 \mathrm{~mL}$ of seawater for culture. The larvae were reared at a density 20 ind./recipient in constant conditions of temperature $(26 \pm$ $1.5^{\circ} \mathrm{C}$ ), salinity (30), $\mathrm{pH}(8.0)$ and in photoperiod regime (12:12 h light:dark cycle) until the megalopal stage. Larvae were fed daily with rotifers Brachionus plicatilis (50 ind./mL), Artemia nauplii (5 ind./mL) and microalgae Thalassiosira sp (initial concentration about $\left.30 \mathrm{cel} / \mathrm{mL}^{4}\right)$. The recipient seawater was changed at every two days, and the larvae were monitored daily for mortality or moults to subsequent stages.

\section{LARVAL FOREGUT DISSECTION}

For both species, at least 10 individuals of the first (ZI), last zoeal stage (ZIV for P. occidentalis and ZV for $U$. vocator) and megalopa were sampled and used for dissection and illustrations. The methodology applied was similar to that accomplished by Abrunhosa et al. (2003). The samples were fixed in formalin solution $10 \%(\mathrm{v} / \mathrm{v})$ for a 24 hours period. Then, they were immersed in aqueous solution of potassium hydroxide $5 \%(\mathrm{KOH})(\mathrm{p} / \mathrm{v})$ and heated to $80^{\circ} \mathrm{C}$ for 30 minutes. Later, the samples were washed with distilled water and immersed in ethylic alcohol 70\% + glycerine solution $(1: 1)$.

\section{ILLUSTRATION AND DESCRIPTIONS OF THE FOREGUT}

After the treatments described above, the larvae of the respective stages were placed in a slide with ethylic alcohol $70 \%+$ glycerine solution $(1: 1)$. The larvae were dissected under an optic microscopy (ZEISS). Fine needles $\left(\mathrm{BD}\right.$ Ultra-Fine ${ }^{\circledR}, 12.7 \times 0.33 \mathrm{~mm}$ ) were used for dissection. The foreguts were extracted and transferred to another slide where they were stained with a 
solution of methylene blue $1 \%$. The foreguts were observed and illustrated in lateral view, aided by a micrometer disc. The terminology used for descriptions of the foregut follows Meiss and Normann (1977), Nishida et al. (1990), Abrunhosa and Kittaka (1997a) and Abrunhosa et al. (2003).

\section{RESULTS}

\section{LARVAL CULTURE}

The complete larval development of $U$. vocator was constituted of 5 zoeal and 1 megalopal stages, while the one of $P$. occidentalis was composed by 4 zoeal and 1 megalopal stages. In $U$. vocator, the larval survival rate until the megalopa stage was $90 \%$, and the larval development period from hatching to megalopa ranged from 10 to 12 days. For P. occidentalis, the larval survival rate was $100 \%$, and the development period until the megalopal stage was about 12 days. The survival rates and development periods of each zoeal stage of $U$. vocator and $P$. occidentalis are shown in the Tables I and II, respectively.

TABLE I

Survival rate (\%) and intermolt period (days) of Uca vocator larvae reared in the laboratory.

\begin{tabular}{c|c|c}
\hline Larval stage & $\begin{array}{c}\text { Survival } \\
(\%)\end{array}$ & $\begin{array}{c}\text { intermolt period } \\
\text { (days) }\end{array}$ \\
\hline Zoea I & 100 & 1 \\
Zoea II & 98 & 2 \\
Zoea III & 98 & 2 \\
Zoea IV & 91 & 3 \\
Zoea V & 90 & 3 \\
Megalopa & $*$ & $*$ \\
\hline *The experiment ended in megalopa and they did not \\
moult to the first juvenile.
\end{tabular}

\section{MORPHOLOGY OF THE LARVAL FOREGUTS}

\section{Uca vocator}

The foreguts of the first and last zoeal stages of $U$. vocator: showed a cardiopyloric valve separating the cardiac from the pyloric chamber, as well a filter press that becomes specialized during the larval development. There is a degree of specialization of the foregut along the larval development where the number of setae and size are increased. After the metamorphosis to megalopal stage, a considerable morphological change in the
TABLE II

Survival rate $(\%)$ and intermolt period (days) of Panopeus occidentalis larvae reared in the laboratory.

\begin{tabular}{c|c|c}
\hline Larval stage & $\begin{array}{c}\text { Survival } \\
(\%)\end{array}$ & $\begin{array}{c}\text { intermolt period } \\
\text { (days) }\end{array}$ \\
\hline Zoea I & 72 & 3 \\
Zoea II & 100 & 2 \\
Zoea III & 100 & 4 \\
Zoea IV & 100 & 3 \\
Megalopa & $*$ & $*$ \\
\hline
\end{tabular}

*The experiment ended in megalopa and they did not moult to the first juvenile.

foregut was observed with the appearance of ossicles of the gastric mill and lateral teeth.

\section{Zoea I (Fig. 1)}

Foregut - Simple, chitinous and lacking - hard structures (total length $1.1 \mathrm{~mm}$ ).

Cardiac chamber - Little larger than pyloric chamber; cardiac wall lacking setae; numerous fine setae on the floor base; cardiopyloric valve redounded and robust bearing many setae on its extension and showing strong setae on the posterior portion.

Pyloric chamber - Bearing fine setae on the posterior portion; fitter press large and well-developed occupying all the inferior portion of the chamber; numerous setae on the inter-ampullary ridge.

\section{Zoea V (Fig. 2)}

Foregut - More complex than stage I and lacking - rigid structures (total length $1.8 \mathrm{~mm}$ ).

Cardiac chamber - Cardiac roof showing fine setae on the roof with row of elongate and fine setae in the anterior portion; posterior portion with numerous rigid and long setae; cardiac wall lacking setae; cardiopyloric valve redounded and large with strong setae almost in all of its extension.

Pyloric chamber - About $2 / 5$ cardiac chamber size; fine setae on the posterior portion of the cardiac roof; filter press specialized, occupying all inferior portion of the chamber; inter-ampullary ridge with rows of elongate and medium setae; ampullary net well-developed and functional. 


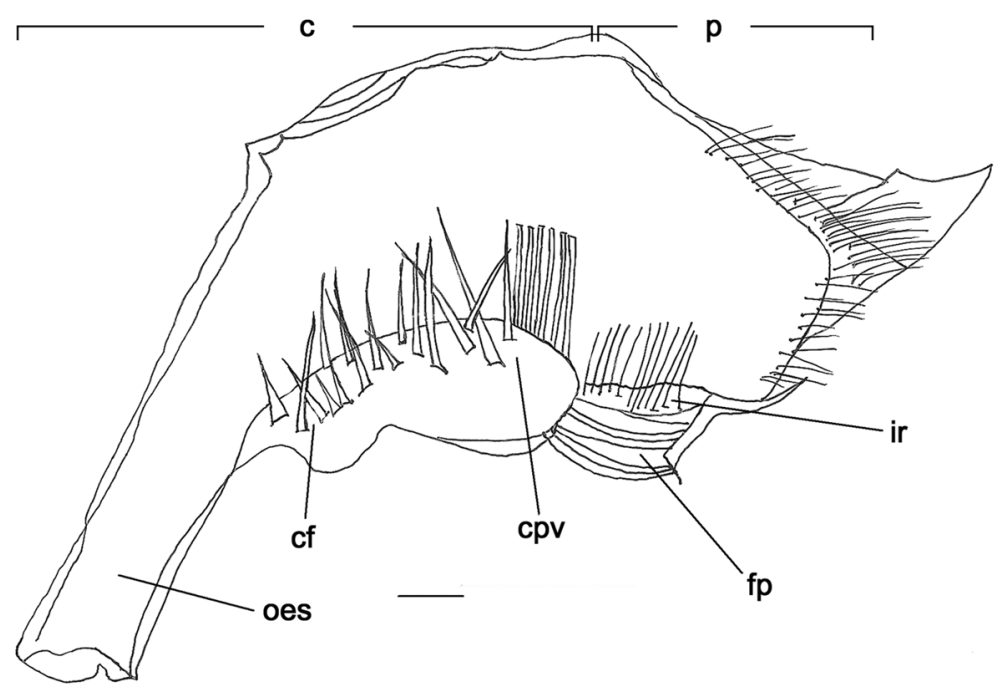

Fig. 1 - Uca vocator. Zoea I foregut in lateral view (right side). Scale bar $=0.3 \mathrm{~mm}$. Abbreviations: $\mathrm{fp}=$ filter press; ir $=$ interampulary ridge; $\mathrm{cpv}=$ cardiopyloric valve; $\mathrm{cf}=$ cardiac floor; oes $=$ oesophagus; $\mathrm{c}=$ cardiac chamber; $\mathrm{p}=$ pyloric chamber.

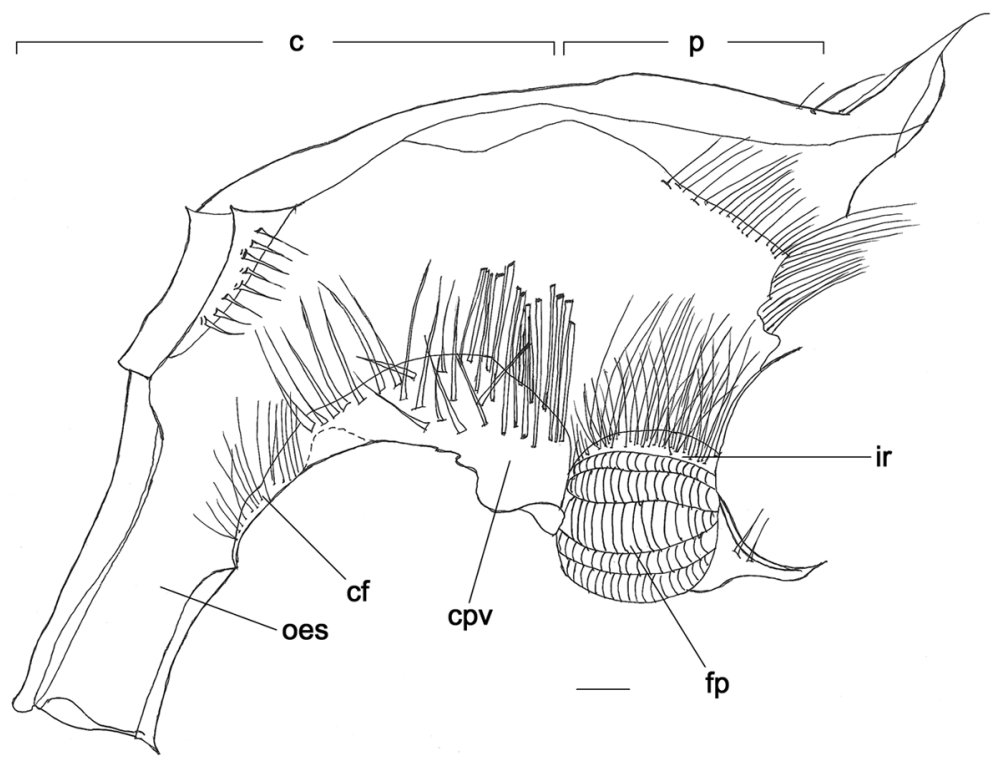

Fig. 2 - Uca vocator. Zoea V (last zoeal stage) foregut in lateral view (right side). Scale bar $=0.4 \mathrm{~mm}$. Abbreviations: fp $=$ filter press; ir $=$ interampulary ridge; $\mathrm{cpv}=$ cardiopyloric valve; $\mathrm{cf}=$ cardiac floor; oes $=$ oesophagus; $\mathrm{c}=$ cardiac chamber; $\mathrm{p}=$ pyloric chamber.

\section{Megalopa (Fig. 3)}

Foregut - Showing a complex gastric mill, oesophageal valve and other rigid structures (total length $3.8 \mathrm{~mm}$ ).

Cardiac chamber - Enlarged dorso-ventrally by plates and gastric mill ossicles (about 3 times the pyloric chamber); cardiac floor showing almost vertically; numerous ossicles of gastric mill present: mesocardiac, pterocardiac; zygocardiac (supporting the lateral teeth), urocardiac (supporting medial tooth), propyloric, exo- pyloric and pyloric. Other ossicles are present such as prepectineal, pectineal, exopyloric, subdentate, inferior lateral cardiac and lateral cardiopyloric; valve cardiopyloric robust and specialized, bearing firm setae on the superior portion (other ossicles as illustrated in Fig. 3).

Pyloric chamber - Fine setae on the posterior portion of the roof; filter press specialized bearing a well-developed and functional ampullary net; inter-ampullary ridge with rows of elongate setae; some ossicles pres- 


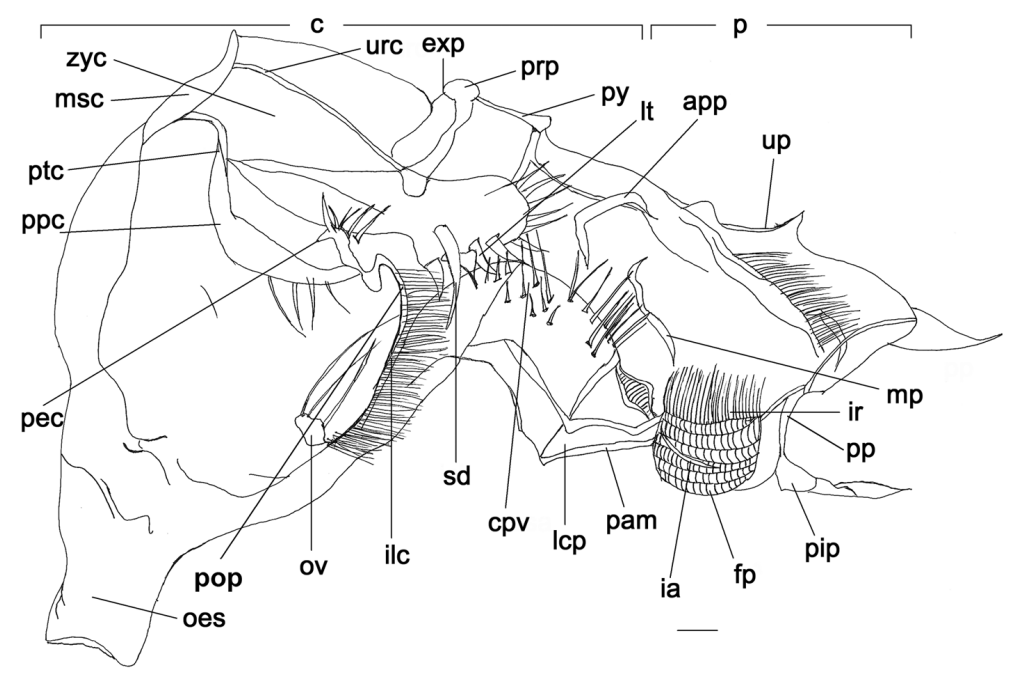

Fig. 3 - Uca vocator. Megalopa foregut in lateral view (right side). Scale bar $=0.4 \mathrm{~mm}$. Abbreviations: app $=$ anterior pleuropyloric ossicle (a pair); $\mathrm{c}=$ cardiac chamber; $\mathrm{cpv}=$ cardiopyloric valve; $\exp =$ exopyloric (a pair); $\mathrm{fp}=$ filter press; ia $=$ inferior ampullary ossicle, ir $=$ interampullary crista; ilc $=$ anterior lateral cardiac ossicle; $1 \mathrm{cp}=$ lateral ossicle of the cardiopyloric valve; $1 \mathrm{t}=$ lateral teeth $(\mathrm{a}$ pair $) ; \mathrm{mp}=\mathrm{middle}$ pleuropyloric ossicle (a pair); msc = mesocardiac ossicle; oes = oesophagus; $\mathrm{p}=$ pyloric chamber; ov = oesophageal valve; pam = pre-ampullary ossicle; $p e c=$ pectineal ossicle (a pair); pip = posterior inferior pyloric ossicle; pop = pos-pectineal ossicle (a pair); $p p=$ pleuro-pyloric ossicle (a pair); ppc = pre- pectineal (a pair); prp = propyloric ossicle; $p t c=$ pterocardiac ossicle; $p y=$ pyloric ossicle; $s d=$ subdentate ossicle $($ a pair); up $=$ uropyloric ossicle; urc $=$ urocardiac ossicle; zyc $=$ zygocardiac ossicle (a pair).

ent: uropyloric, anterior pleuropyloric, posterior pleuropyloric; middle pleuropyloric, pre-ampullary; inferior pyloric, anterior inferior and posterior pyloric ossicle (other ossicles as illustrated in Fig. 6).

\section{Panopeus occidentalis}

Zoea I (Fig. 4)

Foregut - Simple and chitinous (total length $0.72 \mathrm{~mm}$ ).

Cardiac chamber - Showing numerous setae on the cardiac floor; cardiac wall lacking setae; cardiopyloric valve redound and robust with firm and erect setae on the posterior portion.

Pyloric chamber - Pyloric wall lacking setae; pyloric floor showing setae in all portion; filter press well-developed and filling all inferior portion of the chamber; inter-ampullary ridge rows of numerous setae.

\section{Zoea IV (Fig. 5)}

Foregut - more developed compared to zoea I stage, but similar in shape; lacking rigid structures (total length $3 \mathrm{~mm}$ ).
Cardiac chamber - Cardiac floor with a row of elongate setae; cardiac wall with few setae on the posterior portion; cardiopyloric valve redound, large and holding erect and strong setae on the posterior portion; cardiac floor with fine setae in the posterior portion.

Pyloric camber - Filter press specialized and complex, filling all inferior portion of the chamber; inter-ampullary ridge well-developed with rows of medium setae.

\section{Megalopa (Fig. 6)}

Foregut - Showing a complex gastric mill; oesophageal valve and rigid structures (total length $3.5 \mathrm{~mm}$ ).

Cardiac chamber - Enlarged dorsolaterally by the gastric mill ossicles; cardiac floor disposed vertically; cardiopyloric valve specialized and robust; gastric mill ossicles present, such as: mesocardiac, pterocardiac, zygocardiac (supporting the lateral teeth), urocardiac (supporting medial tooth), propyloric, exopyloric and pyloric; other ossicles are observed: prepectineal, pectineal, exopyloric, subdentate, inferior lateral cardiac and lateral cardiopyloric; valve cardiopyloric robust and specialized, bearing firm setae on the superior portion (other ossicles as illustrated in Fig. 6). 


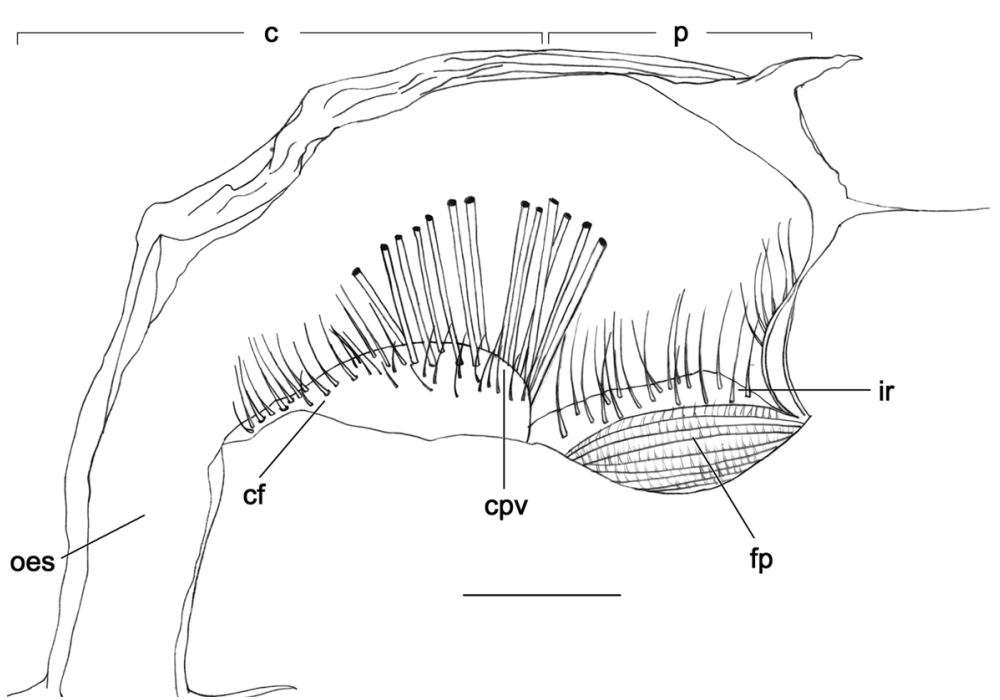

Fig. 4-Panopeus occidentalis. Zoea I foregut in lateral view (right side). Scale bar $=0.18 \mathrm{~mm}$. Abbreviations: $\mathrm{fp}=$ filter press; ir $=$ interampulary ridge $\mathrm{cpv}=$ cardiopyloric valve; $\mathrm{cf}=$ cardiac floor; oes $=$ oesophagus; $\mathrm{c}=$ cardiac chamber; $\mathrm{p}=$ pyloric chamber.

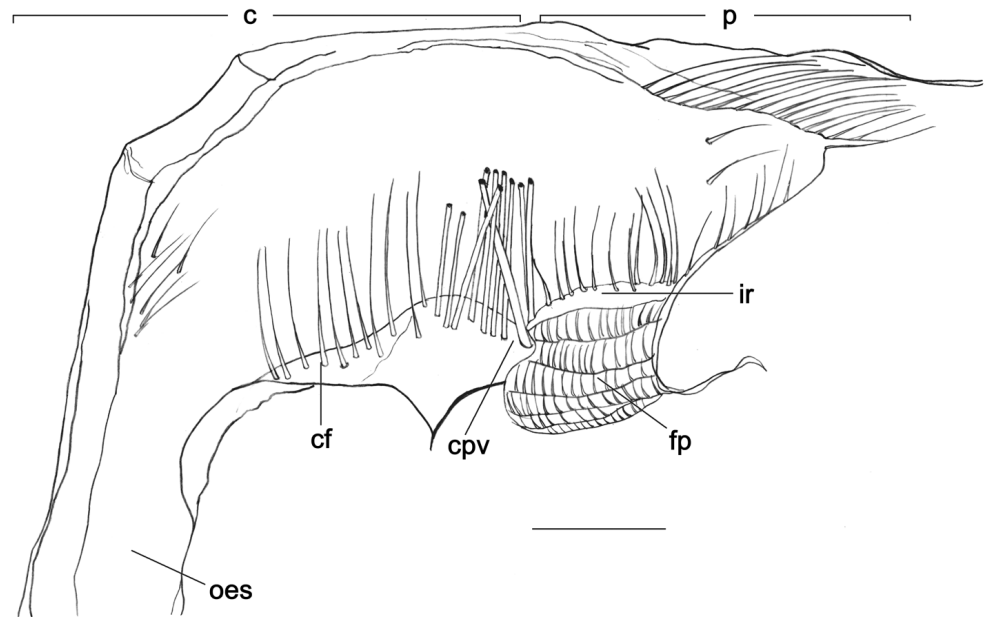

Fig. 5 - Panopeus occidentalis. Zoea IV (last zoeal stage) foregut in lateral view (right side). Scale bar $=0.75 \mathrm{~mm}$. Abbreviations: $\mathrm{fp}=$ filter press; ir $=$ interampulary ridge; $\mathrm{cpv}=$ cardiopyloric valve; $\mathrm{cf}=$ cardiac floor; oes $=$ oesophagus; $\mathrm{c}=$ cardiac chamber; $\mathrm{p}=$ pyloric chamber.

Pyloric chamber - Narrow laterally; filter press specialized showing a well-developed and functional ampullary net; inter-ampullary ridge with rows of long setae; some ossicles present, such as: anterior pleuropyloric, posterior pleuropyloric and middle pleuropyloric, preampullary and inferior posterior pleuropyloric (other ossicles as illustrated in Fig. 6).

\section{DISCUSSION}

In the literature, the majority of the reports on larval development and metamorphose forms (glaucothoe, puerulus, decapodid and megalopa) of decapods are only limited to the descriptions of the general appendages, and detailed information is rather limited regarding the functional morphology of mouthparts, foregut and digestive gland during the larval development. However, the results of these investigations have significantly contributed to improve the larval culture of decapod species (Kittaka 1994, Abrunhosa and Kittaka 1997a, b). Studies about the functional morphology have demonstrated, for example, that there is an expressive reduction of the larval mortality due to non addition of food in cases of lecithotrophic behaviour, which occurs at some stages or along the entire larval development sequence (Kittaka 1988, Kittaka and Ikegami 1988, Abrunhosa and Kittaka 1997a, b). 


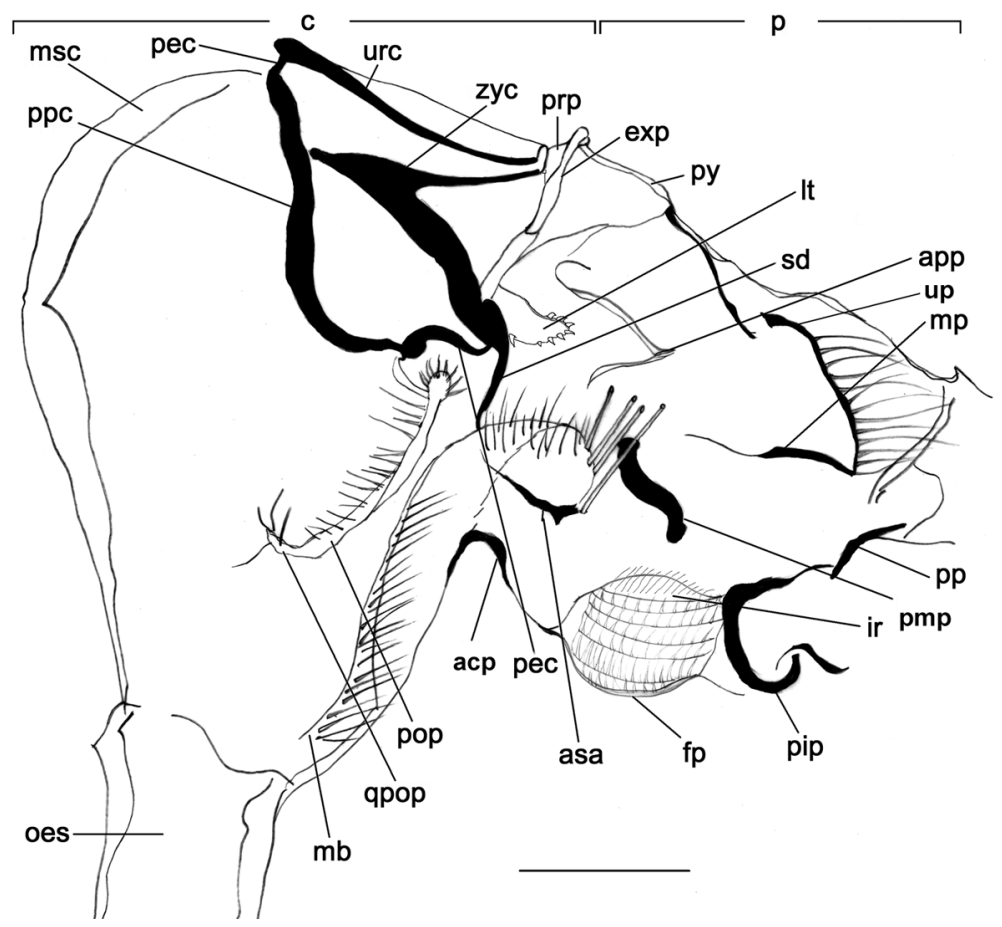

Fig. 6 - Panopeus occidentalis. Megalopa foregut in lateral view (right side). Scale bar $=0.75 \mathrm{~mm}$. Abbreviations: Abbreviations: app $=$ anterior pleuropyloric ossicle (a pair); acp = anterior ossicle of cardiopyloric valve; asa = anterior supra-ampullary ossicle (a pair); $\mathrm{c}=$ cardiac chamber; $\exp =$ exopyloric (a pair); $\mathrm{fp}=$ filter press; ir = interampullary crista; $1 \mathrm{t}=$ lateral teeth (a pair); $\mathrm{mb}=$ main brush; $\mathrm{mp}=$ middle pleuropyloric ossicle (a pair); $\mathrm{msc}=$ mesocardiac ossicle; oes = oesophagus; $\mathrm{p}=$ pyloric chamber; pec $=$ pectineal ossicle (a pair); pip = posterior inferior pyloric ossicle; qpop = "Quill" of pos-pectineal ossicle; pop = pos-pectineal ossicle (a pair); pp = pleuro-pyloric ossicle (a pair); ppc = prepectineal (a pair); prp propyloric ossicle; $p y=$ pyloric ossicle; $\mathrm{sd}=$ subdentate ossicle (a pair); up = uropyloric ossicle; urc $=$ urocardiac ossicle; zyc $=$ zygocardiac ossicle (a pair).

Detailed analyses of the foreguts in the zoeal and megalopal stages of $U$. vocator and $P$. occidentalis showed similarities between these two species in both their structures and functions. The foreguts of the zoeal I stage are morphologically simple, but bearing specific setae and a filter press that is apparently functional. The same pattern were observed in the zoea I larvae. The foreguts of the last zoeal stages, (zoea $\mathrm{V}$ for $U$. vocator and zoea IV for $P$. occidentalis) also lacked gastric mill apparatus however, an increase in the degree of specialization of the foregut was also observed, which showed an increment of setae, but the main difference is in the observance of the cardiopyloric valve and the complexity of the filter press. Therefore, the last zoeal stage of both species shows an increasing in the ability to process small particles of food. These observations corroborate with those of previous studies with crab larvae (Shinkarenko 1979, Factor 1982, 1989, Minagawa and
Takashima 1994, Abrunhosa et al. 2003).

The cardiac chambers of the zoeal stages do not bear gastric teeth strongly indicating that they may not be capable of grinding hard food. However, these larvae are able to feed on soft food particles, such as Artemia nauplii, rotifers, microalgae and other zooplanktonic species available in the aquatic environment. Similarities with the morphological features of the zoea I foregut of decapods were also observed in several other species (Factor 1982, 1989, Nishida et al. 1990, Abrunhosa and Kittaka 1997a, b, Abrunhosa and Melo 2002, 2008, Abrunhosa et al. 2003, Melo et al. 2006). However, some first larvae of the callianissid Lepidophthalmus siriboia have been reported showing only few minute setae in the cardiac and pyloric chambers, as well as a reduced filter press (Abrunhosa et al. 2006). These facts, strongly suggested a non-feeding behaviour of zoea larvae of this species. 
The foregut is an important component of the digestive system for break down food items into fine particles. The elaboration of the gastric mills placed in the cardiac chamber is necessary to the development of the proper digestion of substantial foodstuffs, and also for the mixing of digestive enzymes from the midgut gland (Icely and Nott 1992). Many works listed in the literature show the megalopa of brachyuran crabs as having well-developed mandibles and setose mouthparts (Perkins 1973 for gerynoids; Gore et al. 1982, Webber and Wear 1981 for majids, Abrunhosa et al. 2003, 2006 for ocypodids).

Significant changes in both morphological and anatomical features of the foregut take place during the metamorphosis of $U$. vocator and P. occidentalis from zoea to megalopa stages. These foreguts undergo remarkably morphological changes where newly moulted megalopae bear a highly complex foregut. Such moulting brings about changes in the feeding apparatus that is necessary for the processing substantial food in their natural environment.

\section{ACKNOWLEDGMENTS}

The present work was financed by the Conselho Nacional de Desenvolvimento Científico e Tecnológico (CNPq).

\section{RESUMO}

A alimentação é um importante fator para o sucesso no cultivo larval de espécies de caranguejos. Informações sobre as características morfológicas do estômago podem contribuir para revelar o comportamento alimentar larval ou, se há lecitotrofia em algum, ou até mesmo, em todos os estágios do ciclo larval. No presente estudo, o desenvolvimento estrutural do estômago e as funções digestivas foram examinados em larvas de duas espécies de braquiúros, Uca vocator e Panopeus occidentalis, cultivados em laboratório. Durante o desenvolvimento larval, os estômagos das larvas no primeiro e último estágio de zoea e megalopa foram microscopicamente examinados, descritos e ilustrados. Em ambas espécies, o estômago dos estágios de zoea são desenvolvidos e especializados, apresentando uma válvula cardiopilórica e um filtro pilórico funcionais. O estágio de megalopa possui um moinho gástrico complexo e especializado semelhante àquele encontrado em caranguejos adultos com o aparecimento de estruturas rígidas e calcificadas. Estes resultados apóiam a hipótese de que o comportamento alimen- tar de cada estágio larval está diretamente relacionado à estrutura morfológica do estômago. Tal fato, fortemente indica que todos os estágios larvais de ambos $U$. vocator e $P$. occidentalis necessitam de uma fonte externa de alimento para completar o desenvolvimento larval no ambiente planctônico.

Palavras-chave: sistema digestivo, megalopa, Panopeus occidentalis, estômago, Uca vocator, zoea.

\section{REFERENCES}

Abrunhosa FA, Abrunhosa JP And Aguiar MM. 2003. Development and functional morphology of the foregut of larvae and postlarva of Ucides cordatus (Decapoda, Ocypodidae). Nauplius 11(1): 37-43.

Abrunhosa FA AND KitTAKa J. 1997a. Functional morphology of mouthparts and foregut of the last zoea, glaucothoe and first juvenile of the king crabs Paralithodes camtschaticus, P. brevipes and P. platypus. Fish Sci 63(6): 923-930.

Abrunhosa FA And Kittaka J. 1997b. Morphological changes in the midgut gland and hindgut during the larval and postlarval development of the red king crab Paralithodes camtschaticus. Fish Sci 63(5): 746-754.

Abrunhosa FA And Melo MA. 2002. Morfologia comparativa do estômago do primeiro e último estágios zoea e juvenil I de Macrobrachium rosenbergii (De Man, 1879) (Decapoda, Ocypodidae). Rev Cien Agron 33(2): 65-68.

Abrunhosa FA And Melo MA. 2008. Development and functional morfology of the foreguts of larvae and potlarvae of three crustacean decapods. Braz J Biol 68: 221-228.

Abrunhosa FA, Melo M, Lima JF And Abrunhosa J. 2006. Developmental morphology of mouthparts and foregut of the larvae and postlarvae of Lepidophthalmus siriboia Felder \& Rodrigues, 1993 (Decapoda: Callianassidae). Acta Amaz 36(3): 335-342.

ANGER K. 2001. The biology of decapod crustacean larvae, crustacean issues. Vol. 14. Lisse, The Netherlands: A.A. Balkema Publishers, 419 p.

Anger K, Schreiber D And Montú M. 1995. Abbreviated larval development of Sesarma curacaoense (Rathbun, 1897) (Decapoda: Grapsidae) reared in the laboratory. Nauplius 3: 127-154.

Brosing A, Richter S And Scholtz G. 2002. The foregut-ossicle system of Dromia wilsoni, Dromia personata and Lauridromia intermedia (Decapoda, Brachyura, Dromiidae), studied with a new staining method. Arthr Struct Develop 30: 329-338. 
Castro TS And Bond-Buckup G. 2003. The morphology of cardiac and pyloric foregut of Aegla platensis Schmitt (Crustacea: Anomura: Aeglidae). Mem Mus Vict 60(1): 53-57.

Diele K, Koch V, Abrunhosa FA, Farias J And Simith DJ. 2010. The Mangrove Crab Community of the Caeté Estuary, N-Brazil: Species Inventory, Zonation and Abundance. In: Saint-Paul U and Schneider H (Org), Mangrove Dynamics and Management. $1^{\text {st }}$ ed., Berlim: Springer 211: 1-400.

FACTOR JR. 1982. Development and metamorphosis of the feeding apparatus of the stone crab, Menippe mercenaria (Brachyura, Xanthidae). J Morph 172: 299-312.

FACTOR JR. 1989. Development of the feeding apparatus in decapods crustaceans. In: FELGENHAUER BE, WAtLing L AND Thistle AB (Eds), Crustacean issues, Balkema, Rottherdam 6: 185-203.

Gore RH, Scotto LE And YAnG WT. 1982. Microphrys bicornutus (Latreille, 1825): The complete larval development under laboratory conditions with notes on other Mithracine larvae (Decapoda: Majidae). J Crust Biol 2: 512-534.

ICELY JD AND NOTT JA. 1992. Digestion and absorption. Digestive system and associated organs. In: HARRISON FW And Humes AG (Eds), Microscopic Anatomy of Invertebrates, Wiley-Liss Inc 10: 147-201.

INGLE RW. 1985. Larval development of the mud crab Panopeus occidentalis Saussure, from Bermuda (Crustacea: Xanthoidea: Panopeidae). Bull Br Mus Nat Hist (Zool.) 48: 233-248.

JHA A AND HomechaudHURI S. 2001. Understanding the gastric mill structure of a macrophagous shrimp Metapenaeus monoceros (Fabricius). Curr Sci 80(5): 620-622.

KitTaKa J. 1988. Culture of the palinurid Jasus lalandii from egg to puerulus. Nippon Sui Gak 54(1): 87-93.

KitTAKA J. 1994. Larval rearing. In: Phillips BF, CовB JS AND KITTAKA J (Eds), Spiny lobster management, p. 402-423.

KitTAKA J AND IKEgAmi E. 1988. Culture of the palinurid Panulirus elephas from egg stage to puerulus. Nippon Sui Gak 54(7): 1149-1154.

KittaKa J, Ono K And Booth JD. 1997. Complete development of the green rock lobster Jassus verreauxi from egg to juvenile stage. Bull Mar Sci 61: 57-71.

KunZE J AND ANDERson DT. 1979. Functional morphology of the mouthparts and gastric mill in the hermit crab Clibanarius taeniatus (Milne Edwards), Clibanarius virescens (krauss), Paguristes squamosus McCulloch and
Dardanus setifer (Milene Edwards) (Anomura: Paguridae). Australian J Mar Fresh Res 30: 683-722.

Lemmens JWTJ And KnOtT B. 1994. Morphological changes in external and internal feeding structures during the transition phyllosoma-juvenile in the western rock lobster (Panulirus cygnus, Decapoda: Palinuridae). J Morph 220: 271-280.

MeIss DE AND NoRMAN RS. 1977. Comparative study of the stomatogastric system of several decapod Crustacea. J Morph 152: 21-54.

Melo AM, Abrunhosa FA And Sampaio I. 2006. The morphology of the foregut of larvae of postlarva and Sesarma curacaoense De Man, 1892: a species with facultative lecithotrophy during larval development. Acta Amaz 36(6): 375-380.

Melo GA. 1996. Manual de identificação dos Brachyura (caranguejos e siris) do litoral brasileiro. São Paulo: ed., Plêiade/FAPESP, 604 p.

Mikami S AND TAKashima F. 1993. Development of the proventriculos in larvae of the slipper lobster, Ibacus ciliatus (Decapoda, Scyllaridae). Aquaculture 116: 199217.

Minagawa M And Takashima F. 1994. Developmental changes in larval mouthparts and foregut in the red frog crab, Ranina ranina (Decapoda: Raninidae). Aquaculture 126: 61-71.

NAtEs SF AND MCKenney JR CL. 2000. Ontogenic changes in biochemical composition during larval and early postlarval development of Lepidophthalmus louisianensis, a ghost shrimp with abbreviated development. Comp Bioc Physi 127(4): 459-468.

Nishida S, Quigley BD, Booth JD, Nemoto T AND KitTaKA J. 1990. Comparative morphology of the mouthparts and foregut of the final stage phyllosoma, puerulus, and postpuerulus of the rock lobster Jasus edwardsii (Decapoda: Palinuridae). J Crust Biol 10: 293-305.

PERKINS HC. 1973. The larval stages of the deep sea red crab, Geryon quinquedens Smith, reared under laboratory conditions (Decapoda: Brachyrhyncha). Fish Bull 1: 6982.

Pinn EH, Nikell LA, Rogerson A AND ARKinson RJA. 1999. Comparison of gut morphology and gut microflora of seven species of mud shrimp (Crustacea: Decapoda: Thalassinidae). Mar Biol 133: 103-114.

RIEGER PJ. 1999. Desenvolvimento larval de Uca (Minuca) vocator (Herbst, 1804) (Crustacea, Decapoda, Ocypodidae) em laboratório. Nauplius 7: 1-37. 
SHINKARENKO L. 1979. Development of the larval stages of the blue swimming crab Portunus pelagicus (Portunidae: Decapoda: Crustacea). Australian J Mar Fresh Res 30: 485-503.

SKILlETER GA AND ANDERSON DT. 1986. Functional morphology of the chelipeds, mouthparts and gastric mill of Ozius truncates (Milne Edwards) (Xanthidae) and Leptograpsus variegates (Fabricius) (Grapsidae) (Brachyura). Australian J Mar Fresh Res 35: 785-792.

Suthers IM. 1984. Functional morphology of the mouthparts and gastric mill in Penaeus plebejus Hess (Decapoda: Penaeidae). Australian J Mar Fresh Res 35: 785-792.

Suthers IM AND ANDERson DT. 1981. Functional morphology of mouthparts and gastric mill of Ibacus peronii (Leach) (Paninura: Scyllaridae). Australian J Mar Fresh Res 32: 931-944.
Thessalou-Legaki M, PePPa A AND ZaCharaki M. 1999. Facultative lecithotrophy during larval development of the burrowing shrimp Callianassa tyrrhena (Decapoda: Callianassidae). Mar Biol 133: 635-642.

WEBBER WR AND WEAR RG. 1981. Life history studies on New Zealand Brachyura, 5. Larvae of the family Majidae. New Zealand J Mar Fresh Res 15: 331-383.

Wolfe SH And Felgenhauer BE. 1991. Mouthpart and foregut ontogeny in larval, postlarval, and juvenile spiny lobster Panulirus argus Latreille (Decapoda: Palinuridae). Zool Scripta 20: 57-75. 